\title{
Splenic incidentaloma on routine chest radiography before admission to a nursing home
}

\author{
Hirohisa Fujikawa (1) 1,2 Michiko Hinata ${ }^{2}$
}

'Department of Medical Education Studies, International Research Center for Medical Education, Graduate School of Medicine, The University of Tokyo, Bunkyo-ku, Tokyo, Japan ${ }^{2}$ Department of Internal Medicine, You Home Clinic, Bunkyo-ku, Tokyo, Japan

\section{Correspondence to} Dr Hirohisa Fujikawa; hirohisa.fujikawa@gmail.com

Accepted 21 March 2021

\section{DESCRIPTION}

A 93-year-old female with Alzheimer's dementia underwent a routine plain chest radiography before admission to a nursing home, which incidentally showed an abdominal mass (figure 1). The patient had been seen twice a month by our clinic's visiting physicians and had been doing well with no particular symptoms. Laboratory examinations showed no remarkable findings. Abdominal CT revealed a splenic mass with a diameter of $58 \mathrm{~mm}$ with calcification at the margins, indicating the diagnosis of epidermoid cyst (figure 2). We practised shared decision making with the patient and her family, and it was decided that no further detailed examination or treatment would be performed on the splenic tumour.

Incidental abnormal lesions are defined as abnormalities unrelated to the patient's presenting illness. In the context of the spleen, these lesions mean that the patient has no history of malignancy and no symptoms, such as fever, weight loss and upper abdominal discomfort. Unexpected splenic lesions are frequently identified on CT in daily clinical practice. Although most lesions are benign, clinicians should be alert to warning findings as follows: the presence of solid, contrast-enhancing components and ill-defined lesion borders. ${ }^{1}$ These findings suggest the possibility of potentially more relevant diseases, such as malignancy, abscess and sarcoidosis. Alternatively, splenic incidentaloma detected on chest X-ray is rare. To the best of our knowledge,



Figure 1 Plain chest radiography showing the abdominal mass with calcified margins (red arrow).

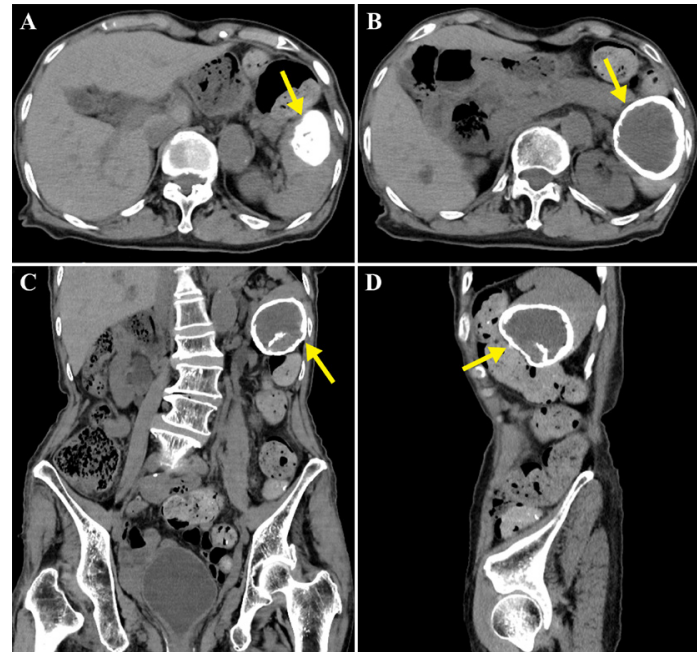

Figure 2 CT showing the splenic mass with wall calcification (yellow arrows) (A, B, axial views; C, coronal view; D, sagittal view).

this is the first case of incidentally identified splenic masses on plain chest radiography.

Splenic epidermoid cysts are uncommon congenital benign lesions. They are a form of non-parasitic primary cysts. They are composed of cystic lesions lined by keratinising and nonkeratinising epithelia, which may be squamous or cuboidal. Symptoms of epidermoid splenic cysts are usually nonspecific. The most common symptoms are a left upper abdominal mass, followed by left upper abdominal pain. ${ }^{2}$ Complications from epidermoid splenic cysts, such as bleeding, infection and rupture, are rare. On imaging examinations, epidermoid of the spleen has a solitary, well-defined cystic lesion, occasionally with plaque-like wall calcification. Surgical therapy is often recommended for symptomatic patients and for cysts larger than $5 \mathrm{~cm}$.

Learning points

- Incidentaloma on plain chest radiography is a rare clinical presentation of splenic masses.

- Splenic epidermoid cysts are uncommon congenital benign lesions and rarely lead to complications, including bleeding, infection and rupture.

- Clinicians should be aware of the possibility of abnormal findings in areas other than the lung fields when reading routine plain chest radiographic images. 
The goal of the surgical treatment is to avoid complications and prevent recurrence.

Routine chest radiography obtained on admission has been a common practice in many hospitals. In addition to that, especially in Japan, routine chest X-rays are often performed before admission to nursing homes mainly to rule out tuberculosis (since Japan is still a tuberculosis middle-burden country). ${ }^{4}$ Clinicians should pay attention to the potential existence of abnormal findings outside the lung fields when reading routine plain chest radiographic images.

Contributors HF acquired data and drafted the manuscript. MH reviewed and supervised the manuscript.

Funding The authors have not declared a specific grant for this research from any funding agency in the public, commercial or not-for-profit sectors.
Competing interests None declared.

Patient consent for publication Obtained.

Provenance and peer review Not commissioned; externally peer reviewed.

\section{ORCID iD}

Hirohisa Fujikawa http://orcid.org/0000-0002-8195-1267

\section{REFERENCES}

1 Karlo CA, Stolzmann P, Do RK, et al. Computed tomography of the spleen: how to interpret the hypodense lesion. Insights Imaging 2013;4:65-76.

2 Chen Y-Y, Shyr Y-M, Wang S-E. Epidermoid cyst of the spleen. J Gastrointest Surg 2013;17:555-61.

3 Gianom D, Wildisen A, Hotz T, et al. Open and laparoscopic treatment of nonparasitic splenic cysts. Dig Surg 2003;20:74-8.

4 Hagiya $\mathrm{H}$, Koyama T, Zamami Y, et al. Trends in incidence and mortality of tuberculosis in Japan: a population-based study, 1997-2016. Epidemiol Infect 2018;147:1-10.

Copyright 2021 BMJ Publishing Group. All rights reserved. For permission to reuse any of this content visit

https://www.bmj.com/company/products-services/rights-and-licensing/permissions/

BMJ Case Report Fellows may re-use this article for personal use and teaching without any further permission.

Become a Fellow of BMJ Case Reports today and you can:

- Submit as many cases as you like

- Enjoy fast sympathetic peer review and rapid publication of accepted articles

- Access all the published articles

- Re-use any of the published material for personal use and teaching without further permission

\section{Customer Service}

If you have any further queries about your subscription, please contact our customer services team on +44 (0) 2071111105 or via email at support@bmj.com.

Visit casereports.bmj.com for more articles like this and to become a Fellow 